\title{
DOBRO WSPÓLNE I INTERES WŁASNY JAKO PROBLEM ETYKI GOSPODARCZEJ
}

\section{Wprowadzenie}

Na jednej z konferencji poświęconej etyce gospodarczej, gdy mowa była o funkcjonowaniu reguł moralnych we współczesnych społeczeństwach, w dyskusji pojawił się argument odwołujący się do ruchu drogowego. Referat piszącego te słowa dotyczył tak zwanego interesu własnego objawiającego się $\mathrm{w}$ formie dokonywanej przez jednostkę kalkulacji indywidualnych kosztów i korzyści. Głos w dyskusji sprowokował mnie do rozpoczęcia tego artykułu kilkoma uwagami na temat ruchu drogowego jako metafory szerszych problemów społecznych. Całość tekstu jednak chciałbym odnieść do zagadnień istotnych dla etycznej refleksji nad gospodarką pożytkującej się perspektywą etyki ładu, nazywanej też etyką instytucjonalną, czy też - co wydaje mi się trafniejsze - etyką reguł gry. Nie jestem w stanie przedstawić tutaj tej koncepcji w całości, chciałbym raczej wykorzystać pewne jej wątki, prezentując własne ujęcie tytułowego problemu.

Celem artykułu jest pokazanie, że możliwa jest refleksja etyczna oddająca sprawiedliwość rynkowym regułom gry, a zatem godzącą się z faktem konkurencji oraz istnienia interesu własnego jako podstawowej motywacji współczesnej jednostki, a jednocześnie niepopadająca w skrajności tak zwanej neoliberalnej ideologii, odrzucającej a priori możliwość korzystnej dla gospodarki (i społeczeństwa) ingerencji państwa. Wypracowywanie takiej perspektywy wymaga między innymi uwzględnienia historycznych odmian 
refleksji etycznej: przednowoczesnej i nowoczesnej (będącej spadkobierczynią Oświecenia) ${ }^{1}$. Współcześnie gospodarka przypomina grę o sumie dodatniej, a zatem konkurencja (nie tylko zresztą $\mathrm{w}$ tej sferze życia) nie jest zjawiskiem negatywnym (wyniszczającym), lecz podstawą zbiorowej i indywidualnej pomyślności. Moralność nie musi być więc wyłącznie moralnością samoograniczania się i dzielenia się z innymi (jak w społeczeństwach przednowoczesnych), lecz powinna być takim regulatorem, który stwarza wszystkim warunki uczciwej rywalizacji (stąd „etyka reguł gry”).

Jak twierdzą współcześni kontynuatorzy ordoliberalizmu Waltera Euckena uprawiający tak zwaną etykę ładu (Ordnungsethik - K. Homann, A. Suchanek, I. Pies, C. Lütge), nie można oczekiwać od konkurujących ze sobą jednostek przestrzegania norm moralnych w sytuacji, gdy większość ich nie przestrzega, a ten, kto chciałby postąpić odwrotnie, czyli moralnie, narażony byłby na pewną przegraną2. Należałoby zatem tworzyć takie normy, które byłyby skuteczne dzięki swoistemu realizmowi „normodawcy”, który nie oczekiwałyby heroizmu od jednostki konkurującej $z$ innymi, w wyniku czego normy te zawierałyby już rodzaj zachęty do ich przestrzegania w postaci wizji przewagi konkurencyjnej (niem. Vorteil, ang. advantage) ${ }^{3}$. Etyka zatem powinna projektować taki właśnie system, nie zaś starać się wpływać wprost na zachowania aktorów sceny społecznej4. Z kolei argument wspomnianego tu już dyskutanta w odpowiedzi na tę właśnie wizję etyki był następujący: jego rodacy, Belgowie, notorycznie nie przestrzegają ograniczeń szybkości, czyli łamią przepisy; czy zatem, skoro przepisy „nie działają", nie dają się wyegzekwować, nie należałoby odwoływać się do sumienia kierowców, do ich indywidualnego poczucia odpowiedzialności?

\section{"Polskie drogi"}

Skuteczność apeli moralnych w nowoczesnym, pluralistycznym społeczeństwie okazuje się często wątpliwa. Nie zmienia to faktu, że nawet dyskusje etyków bardzo często sprowadzają się w ostateczności do takich

\footnotetext{
${ }^{1}$ Być może także takiej, która zasługiwałaby na miano „ponowoczesnej” (jako zdecydowanie wykraczającej poza nowoczesność), aczkolwiek problem ten nie będzie tu rozważany.

${ }^{2} \mathrm{~K}$. Homann, The sense and limits of the economic method in business ethics, Discussion paper nr 2006-5. Wittenberg-Zentrum für Globale Ethik 2006, s. 4-6; zob. też: idem, Morality and advantages, Discussion paper 2006-6. Wittenberg-Zentrum für Globale Ethik 2006.

${ }^{3} \mathrm{~K}$. Homann, Morality and advantages, op. cit.

${ }^{4} \mathrm{Ch}$. Lütge, Fundamentals of order ethics. Law, business ethics and the financial crisis, [w:] Global Harmony and the Rule of Law, ed. by T. Bustamante, O. Onazi, Stuttgart 2012, s. 14.
} 
nawoływań. Właśnie analiza tego, co dzieje się na drogach, zwłaszcza w Polsce, pozwala na ciekawsze wnioski dotyczące ludzkich sumień i zadań refleksji etycznej. Apele o bezpieczniejszą jazdę mają w naszym kraju bardzo długą historię, która jednak nie nastraja optymistycznie co do skuteczności tej metody. Zdarza się, że w ciągu świątecznego kilkudniowego okresu ginie na drogach liczba osób porównywalna z liczbą mieszkańców małej wsi, a w skali roku - nawet całego miasteczka.

Wydawałoby się, że na drodze wszystkim chodzi o to samo. Nawet „pirat drogowy" chce dojechać na miejsce, a nie stracić życie. Kierowców zatem łączy ramowo określony cel i w tym sensie powinni być skłonni, we własnym interesie, do współpracy. Wystarczy jednak przypomnieć sobie sytuacje zwężenia dwupasmowej jezdni. Zamiast współpracować i wjeżdżać ze zmniejszoną szybkością na pozostały jeden pas na zasadzie zapinania zamka błyskawicznego, kierowcy blokują się nawzajem, nie chcą sobie ułatwiać tej przeprawy, i w efekcie wszyscy tracą o wiele więcej czasu, niż wymagałaby tego sytuacja. Już tutaj widać, że dla jednych ważniejszy jest czas, a dla innych "honor" bycia pierwszym. Najbardziej jednoczy wszystkich kierowców wzajemne ostrzeganie się przez policyjnym radarem czy to poprzez mruganie światłami, czy też komunikaty nadawane przez nich przy użyciu tak zwanego CB-radia. Tutaj współpraca (przeciwko komuś lub czemuś) układa się znakomicie. A zatem, chociaż wszyscy chcą dojechać na miejsce, wśród kierowców zaobserwować można silne emocje związane z rywalizacją i chęcią sprawdzenia się.

Nie potrzeba badań naukowych, aby stwierdzić, że Polacy masowo nie respektują ograniczeń prędkości. Jednocześnie ktoś, kto posłuchałby apeli "moralizatorów” i odważyłby się ściśle przestrzegać przepisów, byłby zawalidrogą, a ponadto narażałby siebie na niebezpieczeństwo i szybko doświadczyłby, czym jest najeżdżanie na tył jego auta, trąbienie, wyprzedzanie połączone ze złośliwym zajeżdżaniem drogi, czyli nieomal dosłowne spychanie do rowu. Czy można mieć zatem pretensje o to, że ktoś jedzie tak, jak wszyscy, czyli za szybko, bez przestrzegania wielu innych przepisów, i że za optymalną metodę uznał jeżdżenie "trochę" niezgodnie z prawem, aby nie przeszkadzać innym? Jednocześnie mówi się, że zaufanie jest ważnym elementem życia społecznego. W ruchu drogowym obowiązuje jednak zasada ograniczonego zaufania, która właśnie zwiększa nasze bezpieczeństwo.

Nierespektowanie przepisów, pozytywne waloryzowanie sprytu (jechać za szybko, ale nie dać się na tym złapać), przeświadczenie, że wyprzedzający pokazuje swoją dominująca pozycję wyprzedzanemu, i wiele innych tego typu przekonań - składają się na kulturę ruchu drogowego. Podzielane przez większość przekonania wpływają na zachowania indywidualnych 
użytkowników drogi, stanowią podstawę wtórnej socjalizacji i wychowywania młodych kierowców oraz tworzą poczucie tożsamości Polaka za kierownicą. Z daleka rozpoznajemy kierowcę „z Zachodu”: jedzie wolno, lękliwie, przepuszcza pieszych, gdy tylko chcą wejść na jezdnię, nawet wtedy, gdy zamierzają to zrobić poza wyznaczonymi do tego miejscami (pasami). Jednocześnie, jak pokazują badania, poziom samooceny polskich kierowców jest bardzo wysoki. Jesteśmy mistrzami kierownicy!

Kulturowy aspekt ruchu drogowego to także wszystkie polskie wyobrażenia na temat samochodu, skojarzenia, opowieści o nim i utożsamianie się z nim, czyli wszystko, co można umieścić w rubryce "społeczne życie przedmiotów" ${ }^{\prime \prime}$. Trudno, na przykład, oczekiwać ostrożnej jazdy od kogoś, kto czuje się rycerzem w swojej nowoczesnej zbroi i na swoim mechanicznym rumaku. Zabawne napisy na ramkach tablic rejestracyjnych zdradzają gust kierowcy. „Nie płacz, kiedy odjadę”, mówi kierowcy z tyłu, że jestem szybszy, mocniejszy i oczywiście bardzo męski. Na drodze liczy się pokaz siły, zamożności i władzy („Chroni mnie immunitet”). Już nawet nie chodzi o to, kto bardziej zbliży się do granicy legalności (moralności), ale kto bardziej tę granicę przekroczy. W ten sposób dochodzi do obniżenia wszelkich standardów, pełnej pogardy dla prawa i zupełnego braku świadomości, czym jest moralność. W dobie Internetu i mediów społecznościowych własne wyczyny można zarejestrować i umieścić w Sieci, dokumentując swoją "odwagę" i stosunek do prawa oraz moralności.

Wnioski, które się nasuwają, byłyby następujące. Powinniśmy współpracować na drodze, lecz nie robimy tego. Powinna obowiązywać wspólna troska o bezpieczeństwo, zasada pomagania kierowcom, którzy gorzej sobie radzą, uprzejmość, uśmiech i wzajemne grzeczności, na przykład zwalnianie, które umożliwia innym włączenie się do ruchu. Wszystko to jest co najwyżej rzadkością, ale dla celów teoretycznego wywodu można przyjąć, że nie istnieje. Co można, w odniesieniu do tej społeczności kierowców, uważać za dobro wspólne? Na pewno nie jest nim dojechanie do celu - każdy indywidualnie to osiąga. Być może bezpieczeństwo jest czymś, co wszyscy chcielibyśmy odczuwać, ale jednocześnie subiektywne interpretacje tego, co jest bezpieczne $\mathrm{w}$ danej sytuacji, mogą się znacznie różnić. Jest jednak coś bardziej podstawowego i odpornego na kaprysy indywidualnej interpretacji, z czego korzystać mogą wszyscy, a co zapewnia to bezpieczeństwo: przepisy prawa. Dobro to zaistnieje jednak tylko wtedy, gdy przepisy prawa będą

\footnotetext{
${ }^{5}$ I. Kopytoff, The cultural biography of things. Commoditization as process, [w:] The social life of things. Commodities in cultural perspective, ed. by A. Appadurai, Cambridge 1986, s. 67; autor mówi tutaj wprost o „biografii” samochodów w Afryce jako fenomenie kulturowym zupełnie odmiennym od swoich odpowiedników w USA czy Francji.
} 
przestrzegane. Przy tej wielości kierowców zmierzających w różnych kierunkach i rozmaicie pojmujących sens własnej jazdy - jedynym wspólnym dobrem są przepisy, o przestrzeganie których jednak trzeba dbać, a także nie zapominać o przyjaznych gestach w sytuacji trudnej, której przepisy nie regulują precyzyjnie.

Piszę o tym, aby pokazać, jak bardzo skomplikowane może być życie społeczne, jeżeli przyjrzeć się mu z bliska. Ruch drogowy to mały wycinek tej rzeczywistości międzyludzkiej. A nie wspomniałem tutaj o problemie alkoholu, narkotyków, powrotów młodzieży z dyskoteki nad ranem, szaleństwach motocyklistów, beztrosce rowerzystów, nieodpowiedzialności pieszych, o korzystaniu z telefonów komórkowych za kierownicą, o bardzo rozległym obszarze zarobkowego używania pojazdów na drodze i setkach innych problemów, o których można by napisać całą książkę. Nie jesteśmy w stanie zaapelować skutecznie do sumień kierowców w - wydawałoby się - tak prostej sprawie: jedźmy wolniej, bezpieczniej, bowiem leży to w naszym wspólnym interesie.

Od lat twierdzę, że ruch drogowy odzwierciedla moralność danej populacji oraz inne głęboko zakorzenione kulturowe normy. Aby zachować jednak właściwe proporcje, musimy pamiętać, iż ruch drogowy (pasażerski, z wyłączeniem zawodowych kierowców i całego transportu ciężarowego, a także wszystkich aut dostawczych) nie jest walką o pieniądze, o dobrobyt rodziny i przyszłe szanse dzieci, o poczucie własnej wartości, szacunek środowiska, o to wszystko, o co chodzi przedsiębiorcy, gdy zakłada firmę. Na drodze po prostu jedziemy, aby dojechać do celu. W krajach, w których historia motoryzacji jest dłuższa niż w Polsce, na przykład w USA, tak właśnie się dzieje. Pomimo tradycji używania konia w hodowli bydła, osiągnięć przemysłu motoryzacyjnego oraz symbolicznego znaczenia samochodu auto na co dzień nie jest "rumakiem”, a jedynie urządzeniem codziennego użytku, podobnym do lodówki czy telefonu.

\section{Moralność w gospodarce}

W gospodarce istnieje rzeczywista konieczność konkurowania. Na drodze wszelka rywalizacja jest niepotrzebna i wręcz niepożądana, lecz w gospodarce współczesnej stanowi ona jej podstawę. Gospodarka rynkowa oparta na konkurencji jako jedyna potrafi zaspokajać potrzeby wielkich rzesz ludzkich 6 . W odniesieniu to tej sfery używa się takich pojęć filozoficz-

${ }^{6}$ Zdanie to jest zwykłym stwierdzeniem faktu, a nie deklaracją światopoglądową, w szczególności opowiedzeniem się za tak zwaną ideologią neoliberalną. Jeśli już, to raczej za ordoliberalną. 
nych, jak interes własny, czy ekonomicznych, jak maksymalizowanie zysku (szerzej: korzyści), poddane kalkulacji ryzyko, zwrot z inwestycji. Tutaj też chcemy widzieć pewne reguły, które wszystkim dawałyby równe szanse. Rola prawa, procedur, instytucji jest więc podstawowa. Jednocześnie pojawia się pytanie: gdzie jest miejsce na dobro wspólne, skoro każdy myśli o własnej kieszeni?

Tradycyjnie już formułuje się ten problem poprzez pytanie: jak pogodzić prywatne egoizmy z troską o dobro wspólne? Pytanie to jednak przesądza już odpowiedź, bowiem zakłada właśnie ową konieczność "godzenia" sprzecznych tendencji. Czy zatem tak mielibyśmy widzieć gospodarkę, ten kluczowy dla przetrwania wspólnoty podsystem społeczny? Czyżby ewolucja społeczeństw zachodnich doprowadziła do powstania tworu targanego wewnętrznymi sprzecznościami? Ewentualnie, cudowne działanie niewidzialnej ręki rynku mogłoby pogodzić przeciwstawne dążenia, ale i tak punktem wyjścia byłoby coś, czego większość ludzi nie oceniałaby pozytywnie: założony brak współpracy i innych wspólnotowych odruchów.

Krótko mówiąc, jeśli zakładamy, że egoizm jest punktem wyjścia, to nie możemy spodziewać się niczego dobrego już na samym starcie ${ }^{7}$. Nie przekonuje wielu krytyków gospodarki rynkowej utylitarne rozumowanie, które podkreśla znaczenie konsekwencji, czyli dobrych skutków społecznych owego indywidualnego rozpychania się łokciami. Słyszy się więc pogląd, iż nie może być moralną sfera, w której pochwala się egoizm. Argument ten jest jednak wadliwy - jak twierdzą między innymi przedstawiciele etyki ładu - bowiem konkurencja gospodarcza nie jest oparta ani na dobrych, ani na złych intencjach, lecz na uregulowaniach prawnych (a także moralnych), które gwarantują równość szans. Z kolei nasze rozumienie konkurencji nie może opierać się na ewentualnym przeciwstawianiu egoizmu (zła) i altruizmu (dobra), myślenia o własnych korzyściach - myśleniu o korzyściach dla wspólnoty, indywidualnej ekspansji - samoograniczeniu. Myślenie o gospodarce nie może też opierać się na przekonaniu, iż dobre intencje przynoszą zawsze dobre skutki, a złe - złe, że moje zaplanowane samoograniczenie, poświęcenie czy asceza będą służyć skutecznie innym, czyli prowadzić do dobra wspólnego. Odrzuca się zatem takie rozumienie etyki, które zakłada, iż powinna ona apelować do sumienia jednostki o samoograniczenie i dzielenie się z innymi. Tradycja ta mocno jednak tkwi w dzisiejszym myśleniu religij-

7 Ten punkt widzenia reprezentuje wielu teoretyków zarządzania i etyków biznesu: zakładamy egoizm jednostki, a zatem takąż wizję społeczeństwa przekazujemy studentom. Ostatecznie więc trudno się dziwić, że taką, a nie inną gospodarkę mamy. Zob. S. Ghoshal, Bad management theories are destroying good management practices, "Academy of Management. Learning \& Education" 2005, vol. 4, nr 1. Nie do końca mogę się z tym zgodzić. 
nym, a także codziennym, potocznym, i staje się źródłem łatwego moralizowania i krytykowania tak zwanego kapitalizmu.

Prawdę mówiąc, trudno wyobrazić sobie dzielenie się z innymi w dzisiejszym, zglobalizowanym świecie. Dylematy te opisuje, między innymi, Kwame A. Appiah w pracy pod znamiennym tytułem: Cosmopolitanism. Ethics in a world of strangers ${ }^{8}$. Czy mogę $\mathrm{w}$ prosty sposób podzielić się wodą lub jedzeniem z głodującymi tysiące kilometrów stąd dziećmi? W jaki sposób miałbym naśladować Miłosiernego Samarytanina? Jak miałbym kochać swojego bliźniego, który wcale nie jest „blisko"? Istnieje tak wiele „technicznych" kwestii, że okazuje się, iż tradycyjne teorie moralne, włączywszy w to etykę chrześcijańską, okazują się mało przydatne. Można zatem mówić - jak przekonuje nas Onora O'Neill - o adekwatności lub użyteczności teorii moralnych ${ }^{9}$.

Apele do jednostek o samoograniczenie wyraźnie zdradzają swój rodowód i swoje założenia. Są owocem refleksji zakładającej istnienie małej grupy, bezpośrednich kontaktów jej członków, możliwości egzekwowania wspólnotowych reguł oraz zaprowadzenia wspólnotowego konsensusu co do treści propagowanych norm. Jednakże $\mathrm{w}$ takiej wspólnocie już nie żyjemy. Czy zatem wolno nam powiedzieć, że potrzebujemy innej etyki? Czy nie zabrzmi to aż nadto relatywistycznie? Czy istnieje coś takiego, jak przestarzały i nieaktualny system norm moralnych? Czy można etykę dostosowywać do (współczesnych) okoliczności i nowych wyzwań?

Jakkolwiek by to nie brzmiało - tak właśnie się dzieje. Na naszych oczach dokonują się na przykład przemiany obyczajowe, które stają się przedmiotem zaciekłych debat publicznych. W efekcie zawsze zmienia to powszechny odbiór tych zagadnień, chociażby tylko odrobinę $\mathrm{w}$ danym momencie. Etyka współcześnie bardziej kojarzy się debatą aniżeli odgórnie narzuconym punktem widzenia; bardziej z umiejętnością przekonywania aniżeli z metafizycznym uprawomocnieniem ${ }^{10}$. Zmienność etycznej perspektywy dotyczy także gospodarki i refleksji na regułami obowiązującymi w tej sferze życia społecznego. Wystarczy prześledzić ewolucję stosunku chrześcijaństwa do handlu, pieniądza i problemu pobierania odsetek od pożyczonej 2008

8 Zob. K.A. Appiah, Kosmopolityzm. Etyka w świecie obcych, tłum. J. Klimczyk, Warszawa

${ }^{9} \mathrm{O}$. O'Neill, The moral perplexities of famine and world hunger, [w:] Matters of life and death. New introductory essays in moral philosophy, second edition, ed. by T. Regan, New York 1986, s. 294-297.

${ }^{10} \mathrm{Zob}$. H. Blumenberg, An anthropological approach to the contemporary significance of rhetoric, [w:] After Philosophy. End or Transformation?, ed. by K. Baynes [et al.], Cambridge (Mass.) 1987, s. 436; zob. także: K. Homann, The sense and limits of the economic method in business ethics, op. cit., s. 6 . 
sumy. Paradoksalnie, wielki krytyk Oświecenia i nowoczesności, Alasdair MacIntyre, również jest zdania, że moralność zmienia się wraz ze społecznym kontekstem: „Pojęcia moralne są ucieleśnione w formach życia społecznego i są po części elementami tego życia"11.

Jeżeli odróżnimy etykę (refleksję nad moralnością) od moralności (zasad, którymi kierujemy się w życiu), to zasada zmienności obowiązuje $\mathrm{w}$ obu przypadkach. Moralność także dostosowuje się do swoich czasów (wraz ze swoim etycznym uprawomocnieniem) i nie należy wcale rozumieć tego jako moralnego oportunizmu, wymuszonej rezygnacji $\mathrm{z}$ własnych zasad, na przykład w skrajnych, okupacyjnych warunkach. Chodzi bowiem o sytuacje codzienne. Indywidualna postawa heroiczna Don Kichota nie sprawdza się w czasach nieheroicznych. Ludzie w dłuższym okresie nie mogą kierować się regułami moralnymi, które nie pozwalają im funkcjonować, a w rezultacie - przetrwać. Podkreślam: chodzi o zmiany, które dokonują się wraz z ewolucją kontekstu kulturowego, a nie o jednorazowe strategiczne przystosowanie się, na przykład do warunków więziennych, w celu przeżycia. Historyczne analizy pokazują, że moralność zmienia się wraz z czasami. Można oczywiście argumentować, iż etyka musi być zakorzeniona w sferze niezmiennych wartości i norm, ale trudniej utrzymać to normatywne stanowisko w obliczu analiz historycznych. Można też odwoływać się do przykładu wczesnych chrześcijan we wrogim im świecie i utożsamiać moralność $\mathrm{z}$ heroicznym trwaniem przy określonych, utrwalonych w tradycji zasadach. Nie sposób jednak zignorować faktu, iż tak naprawdę etyka pierwszych chrześcijan „skierowana” była ku raczej bliskiej przyszłości i ku celom poza tym światem ${ }^{12}$. Na "tym" świecie jednak to Rzym upadł, a Europa, politycznie i kulturowo, ufundowana została na chrześcijaństwie. Sama moralność chrześcijańska nie pozostała jednak niezmienna przez ponad dwa tysiące lat i do dzisiaj stawiać musi czoła wielu nieznanym w przeszłości wyzwaniom.

Myśląc o tej ewolucji świata zachodniego, wyróżnić można dwa typy regulacji moralnej: przednowoczesny i nowoczesny. Odpowiadają im dwa modele społeczeństwa, opisywane wielokrotnie przez historyków i socjologów, a w szczególności przez Ferdynanda Tönniesa w XIX wieku przy pomocy terminów Gemeinschaft $i$ Gesellschaft ${ }^{13}$. Oczywiście, w historii społeczeństw nie ma zwykłego następstwa „etapów rozwoju” i dawne formy

11 A. MacIntyre, Krótka historia etyki. Filozofia moralności od czasów Homera do XX wieku, tłum. A. Chmielewski, Warszawa 2002 s. 30.

${ }_{12}$ Zob. poniżej, przypisy 18 i 19.

${ }^{13}$ F. Tönnies, Wspólnota i stowarzyszenie. Rozprawa o komunizmie i socjalizmie jako empirycznych formach kultury, tłum. M. Łukaszewicz, Warszawa 1988, s. 328 i passim. 
współistnieją z nowymi, a na obrzeżach (a nawet w centrum) pluralistycznych społeczeństw nowoczesnych wciąż mogą istnieć społeczeństwa tradycyjne.

\section{Przednowoczesność i nowoczesność}

W społecznościach antycznych i średniowiecznych (przednowoczesnych) życie toczyło się w małych wspólnotach, w których nikt nie był anonimowy, a działania jednostek podlegały bezpośredniej kontroli innych ludzi. Za nieprzestrzeganie reguł groziło na przykład wydalenie ze wspólnoty lub inne bezpośrednie sankcje, niczym kara wymierzona przez sprawiedliwego pana. Istniał więc konsensus co do podstawowych wartości i brakowało możliwości kontestowania tychże (nie mówiąc już proponowaniu nowych). Gospodarka miała charakter gry o sumie zerowej, w której bogacenie się jednych oznaczało ubożenie innych. Z tego też powodu moralne było ograniczanie się $\mathrm{w}$ dążeniu do bogactwa, a nadmierne żądze $\mathrm{w}$ tej materii - piętnowane.

Społeczeństwo nowoczesne to anonimowa, pluralistyczna i zatomizowana zbiorowość, z której nie można nikogo w prosty sposób wykluczyć, a napomnienia i apele moralne nie działają. Nawet ewidentne przestępstwo musi być traktowane zgodnie z wszelkimi procedurami i nigdy nie spotyka się $\mathrm{z}$ natychmiastową karą. $\mathrm{W}$ takim społeczeństwie istnieje możliwość wpływania na kształt otoczenia społecznego i reguł gry. Gospodarka przypomina grę o sumie dodatniej: konkurujące jednostki bogacą się nie kosztem innych, lecz dzięki innym, którzy bogacą się również.

Gdy mówimy o "przestarzałej etyce”, chodzi o sytuację, w której pewne kategorie nie tylko nie objaśniają nam już świata, nie tylko nie potrafią wygenerować potrzebnych regulacji moralnych, lecz prowadzą do nierozwiązywalnych sprzeczności i dylematów, co podkreślają także przedstawiciele etyki instytucjonalnej ${ }^{14}$. W szczególności dotyczy to gospodarki opartej na konkurencji i dążeniu do maksymalizacji zysku. Z punktu widzenia etyki przednowoczesnej będzie ona zawsze niemoralna, bowiem oparta na indywidualnych kalkulacjach, czyli egoizmie. Zawsze też pojawiać się będą oskarżenia o brak dbałości o dobro wspólne, niedzielenie się z innymi i - tak jak to było przy okazji niedawnego kryzysu finansowego - chciwość.

$14 \mathrm{Ch}$. Lütge, Economic ethics, business ethics and the idea of mutual advantages, "Business Ethics. An European Review" 2005, vol. 14, nr 2, s. 108. 
Pojęcie chciwości oraz średniowieczna nauka o grzechu mogą być kluczem do zrozumienia przednowoczesnego punktu widzenia. Moralność tego okresu zalecała panowanie nad namiętnościami, które mogły przecież prowadzić do grzechu, a przede wszystkim zakłócać spokój zagłębionego $\mathrm{w}$ modlitwie mnicha i uniemożliwiać osiągnięcie wewnętrznej harmonii i wolności od wszelkich pasji (aphateia). Z biegiem czasu adresatami stają się wszyscy chrześcijanie, a nauka o grzechu i cnocie pełni rolę fundamentu „świeckiej” moralności, formułującej społecznie akceptowane formy pożądania15. Chciwość była uważana za najcięższy grzech, bowiem oznaczała odchodzenie od pierwotnej równości wszystkich ludzi, a także zgubne z eschatologicznego punktu widzenia zaprzedanie się sprawom doczesnym. Myśl chrześcijańska ewoluowała, i z czasem bogactwo przestało uniemożliwiać zbawienie. Wciąż jednak nakładała na bogatych obowiązek dzielenia się z biednymi zgodnie z wczesnochrześcijańską przypowieścią o winorośli, która potrzebuje wiązu, aby wspiąć się do góry i wydać owoc. Bogaci pomagają biednym - biedni odpłacają się modlitwą, której bogaci potrzebują dla zbawienia duszy ${ }^{16}$.

Oczywiście, nie jest to jeszcze cały kontekst kulturowy, w którym pojawia się pojęcie chciwości. W czasach przednowożytnych zachłanność i pożądanie bogactwa też zresztą miało inny sens niż dzisiaj, jak przekonuje nas Jacques Le Goff. Nie chodziło wcale o gromadzenie pieniędzy we współczesnym znaczeniu słowa "pieniądz". Do XII wieku nie mówiono o bogatych i biednych w sensie ekonomicznym, nie „rozliczano” gospodarki z jej cnót i grzechów, bowiem nie wyróżniano pojęciowo gospodarki jako systemu całościowego, istniejącego ponad gospodarstwami domowymi. Rozróżniano potentes oraz humiles, potężnych i słabych, a zatem ówczesny „bogacz” posiadał przede wszystkim władzę polityczną, dysponował dużymi obszarami ziemi i armią służących mu ludzi ${ }^{17}$. Problemy sprawiedliwości, równowagi społecznej i szans na zbawienie dotyczyły właśnie owych możnych, a nie „bogatych” w dzisiejszym rozumieniu. A zatem, o czym będzie jeszcze mowa później, problem równoważenia rozmaitych skłonności i namiętności ludzkich miał charakter bardziej - jak powiedzielibyśmy dzisiaj - polityczny aniżeli ekonomiczny.

Charakter etyki przednowożytnej dobrze oddają analizy Alisdaira MacIntyre'a dotyczące paradoksu etyki chrześcijańskiej. Wprawdzie w drugim

15 R. Newhauser, The seven deadly sins as cultural constructions in the Middle Ages, www.trinity.edu/rnewhaus/outline.html (dostęp: 1.03.2015 r.).

${ }^{16} \mathrm{R}$. Newhauser, The early history of greed. The Sin of avarice in Early Medieval thought and literature, Cambridge (Mass.) 2000, s. 5-22.

17 J. Le Goff, Money and the Middle Ages, Cambridge (Mass.) 2012, s. 2 i 148. 
wydaniu Krótkiej historii etyki autor wycofuje się z radykalizmu swoich wcześniejszych stwierdzeń, niemniej - uważam - jego pierwotna diagnoza wiele nam pozwala zrozumieć z dzisiejszych poglądów krytyków Oświecenia, nowożytnej gospodarki, a przede wszystkim współczesnych społeczeństw pozbawionych "głębszych” więzi wspólnotowych ${ }^{18}$.

Paradoksem etyki chrześcijańskiej - pisze MacIntyre - jest właśnie to, że zawsze starała się wypracować kodeks postępowania dla społeczeństwa jako całości na podstawie przykazań pierwotnie adresowanych do jednostek lub małych wspólnot, aby odizolowały się od reszty społeczeństwa. Dotyczy to zarówno przykazań etyki Jezusa, jak i św. Pawła. Jezus i św. Paweł głosili etykę, która miała spełnić swoje zadanie podczas krótkiego okresu, zanim Bóg ostatecznie ustanowi królestwo mesjańskie i historia zakończy bieg19.

Niezależnie od tego, ta wizja społeczeństwa - co oczywiste - zakorzeniona jest $\mathrm{w}$ pojęciach swojego czasu, charakterystycznych dla feudalnej struktury społecznej.

Kiedy św. Anzelm wyjaśnia stosunek człowieka do Boga, czyni to za pomocą przykładu wasali nieposłusznych wobec feudalnego suwerena. Kiedy wyjaśnia różne powinności, które aniołowie, kler i ludzie świeccy dłużni są Bogu, porównuje je do powinności tych, którzy - odpowiednio - otrzymują za swą służbę lenno na stałe, tych, którzy służą w nadzieli otrzymania takiego lenna, oraz tych, którzy otrzymają zapłatę za ofiarowane służby, ale nie mają nadziei na stałość ich pozycji. Należy koniecznie zauważyć, że chrześcijaństwo, które aby wyrazić własne normy etyczne, musi być ujmowane $\mathrm{w}$ kategorie feudalne, odbiera sobie tym samym sposobność krytyki feudalnych stosunków społecznych ${ }^{20}$.

To ostatnie zdanie jest echem marksistowskich poglądów młodego MacIntyre'a, niemniej wskazując na przywiązanie etyki chrześcijańskiej do określonej wizji społeczeństwa i, rzecz jasna, modelu gospodarki, jednocześnie być może w sposób niezamierzony - sygnalizuje on cały szereg problemów, które może ona mieć z przekraczaniem pewnego horyzontu myślowego w sytuacji zderzenia ze społeczeństwem i gospodarką innego typu.

${ }_{18} \mathrm{~W}$ pierwszym wydaniu autor podkreślał fakt, iż etyka chrześcijańska oferowała kodeks moralny adresowany do małych wspólnot, których zadaniem było czekać w izolacji na powtórne przyjście Chrystusa. We wstępie do wydania drugiego dokonuje korekty tego poglądu. W kodeksie tym są przykazania dotyczące zarówno oczekiwania na mające nadejść wydarzenia, jak i wskazówki odnoszące się do życia doczesnego, które w wymiarze zbiorowym trwać może o wiele dłużej. Zob. A. MacIntyre, op. cit., s. 14.

${ }^{19}$ Ibidem, s. 161

${ }^{20}$ Ibidem, s. 162 


\section{Interes własny w społeczeństwie nowożytnym}

Powstawanie nowego spojrzenia na gospodarkę w świecie, który nie ma się skończyć wkrótce, wymagało odczarowania wielu starożytnych jeszcze pojęć związanych z ludzkimi namiętnościami, skłonnościami i postrzeganiem innych ludzi. Historyczna analiza idei dokonana przez Alberta O. Hirschmana bardzo dokładnie ten proces śledzi. I wcale nie jest tak, jak sądzą niektórzy krytycy współczesności, iż dawna chciwość nazywana jest od czasów Oświecenia interesem własnym, z czego wynikałoby, iż albo kapitalizm zbudowano na ludzkich wadach, tyle że nazywanych inaczej, albo też dysponuje on cudownym mechanizmem przekształcania indywidualnej chciwości w publiczne dobro. Tak naprawdę idea "niewidzialnej ręki” pojawia się po raz pierwszy w traktacie $O$ duchu praw Monteskiusza i to nie w związku z pogonią za pieniądzem, lecz z działaniem w imię honoru ${ }^{21}$.

Zdaniem Hirschmana, przełomem była renesansowa teoria rządzenia państwem, która wymagała lepszej znajomości natury człowieka. „W epoce renesansu narastało przekonanie, które $\mathrm{w}$ wieku XVII przerodziło się w pewność, że ani moralizująca filozofia, ani też przykazania religii nie mogą dłużej powstrzymać destrukcyjnych namiętności ludzkich"22. Krótko mówiąc, studia nad naturą ludzką oraz nowa teoria państwa doprowadziły do przekonania, iż to państwo powinno przekształcać destrukcyjne namiętności w konstruktywne siły. Już Pascal posługiwał się rozumowaniem bliskim „niewidzialnej ręce” Adam Smitha. Giambattista Vico, bliski sercu dzisiejszym kulturoznawcom, twierdzil, iż ustawodawstwo "przekształca zatem okrucieństwo, skąpstwo, ambicję, trzy wady wypaczające cały rodzaj ludzki, w rzemiosło wojenne, handel i politykę, tworząc potęgę, bogactwo oraz mądrość republik. Tak więc te trzy wielkie przywary, które niewątpliwie zniszczyłyby ród ludzki, stają się źródłem społecznej szczęśliwości"23.

W XVIII wieku upowszechniła się koncepcja równoważenia destrukcyjnych namiętności poprzez przeciwstawianie jednej - drugiej. W ten sposób nie potrzeba odgórnej moralnej pedagogiki, bowiem wystarcza sam rozsądek jako sztuka „wybierania namiętności, którymi powinniśmy się kierować dla własnego szczęścia" - jak twierdził baron Holbach²4. Moraliści zatem powinni odwoływać się do poczucia interesu, czyli namiętności, które pełnią ową funkcję równoważącą. Z czasem zaczęto interesy przeciwstawiać na-

${ }^{21}$ A. Hirschman, Namiętności i interesy. U intelektualnych źródeł kapitalizmu, tłum. I. Kopińska, Kraków 1997. s. 22.

22 Ibidem, s. 26.

${ }^{23}$ G. Vico, Nauka nowa, tłum. J. Jakubowicz. Warszawa 1966, § 132-133.

24 P.-H. d'Holbach, System przyrody, t. I, tłum. K. Szaniawski, Warszawa 1957, s. 399. 
miętnościom, czyli wzgląd na własne korzyści, namysł i kalkulację - temu, co niekontrolowane i prowadzące do zguby ${ }^{25}$. Jak pisze Hirschman:

W licznych traktatach o namiętnościach, które ukazały się w XVII wieku, trudno znaleźć jakąkolwiek zmianę w ocenie chciwości jako namiętności „najwstrętniejszej ze wszystkich" czy też jako najbardziej śmiertelnego ze śmiertelnych grzechów, co było jej przypisane od końca średniowiecza. Jednak gdy tylko zarabianie pieniędzy zostało nazwane „interesem”, i w tym przebraniu zaczęło konkurować z innymi namiętnościami, zostało nagle zaakceptowane, a nawet obdarzone misją powstrzymywania namiętności od dawna uważanych za nieporównanie bardziej naganne26.

Dzięki temu Monteskiusz uważał, iż handel łagodzi obyczaje i może być przeciwstawiony wielu zgubnym namiętnościom charakteryzującym zwłaszcza możnych, którzy w miarę rozwoju gospodarki opartej na kapitale coraz rzadziej dokonywali zamachu na majątki swoich bankierów. Oni także myśleli $\mathrm{w}$ kategoriach interesu własnego, bowiem nadużywanie władzy przestawało im się opłacać. Stąd też motto całej pracy Hirschmana, zaczerpnięte z dzieła Monteskiusza: „I szczęściem dla ludzi jest, że znajdują się w położeniu, w którym, gdy namiętności podsuwają im złe zamiary, mają wszakże interes $\mathrm{w}$ tym, aby ich nie spełnić" 27 . Trudno nie zauważyć, iż wyłanianie się pojęcia interesu $\mathrm{w}$ roli czynnika stabilizującego ludzkie namiętności, w tym przede wszystkim szaleństwa możnych tego świata (owych potentes), dokonywało się równocześnie zarówno w polityce, jak i gospodarce, które, tak naprawdę, trudno było rozdzielić. Na ile dzisiaj jest to możliwe, jest już osobną kwestią.

Efektem oświeceniowej filozofii jest więc takie rozumienie interesu własnego, którego nie trzeba i nie można przeciwstawiać dobru wspólnemu. Nowożytne gospodarowanie wspiera interes publiczny - jak pisał Benjamin Friedman - nie wbrew interesowi własnemu, lecz właśnie dzięki niemu ${ }^{28}$. W ten sposób przednowoczesna etyka traci swoje oparcie w wąskowspólnotowych formach życia społecznego, a przede wszystkim traci swoją skuteczność, czyli możliwość wpływania na zachowania jednostek.

${ }^{25}$ A. Hirschman, op. cit., s. 39. Podsumowuje te przemiany także polski badacz: „w kulturze nowożytnej, to jest na przestrzeni od XVI do XVIII wieku, doszło do wykształcenia się i upowszechnienia wśród świeckiej elity umysłowej wzoru osobowego rozumnego egoisty, to znaczy takiego egoisty, który chce i potrafi współżyć i współdziałać z innymi, ale nie czyni tego z miłości czy z zewnętrznego przymusu - jak człowiek czasów średniowiecza - lecz $\mathrm{z}$ racjonalnego wyrachowania, z dodatniego bilansu strat i zysków"; Z. Drozdowicz, O rozumnym egoizmie $i$ wyrachowanym altruizmie, [w:] Horyzonty ponowoczesności. Rozmowy z Zygmuntem Baumanem, część 2, red. J. Sójka, Poznań 1995, s. 61.

${ }^{26}$ A. Hirschman, op. cit., s. 45.

${ }^{27}$ Monteskiusz, O duchu praw, [cyt. za:] A. Hirschman, op. cit., s. 66.

28 B.M. Friedman, The moral consequences of economic growth, New York 2005, s. 40. 


\section{Zakończenie: państwo na straży ładu moralnego}

Przywoływana przez etykę ładu gra o sumie dodatniej, możliwość sytuacji „wygrana - wygrana”, ma stworzyć nową perspektywę widzenia gospodarki, także pod kątem obowiązujących tu zasad. Etyka opierać się tutaj ma na nowych kategoriach myślowych (win-win semantics) ${ }^{29}$.

Wymiana rynkowa opisywana przez Smitha nie była wolna od zobowiązań moralnych, przez co nie pozbawiała się całkowicie pewnego ideału wspólnotowości, aczkolwiek zgodnego z duchem swojego czasu. Handel wykształcał nowe typy cnót jednostkowych, takie jak: pracowitość, wytrwałość, przewidywalność, pokojowe odnoszenie się do ludzi obcych ${ }^{30}$. „Wspólnota”, która stanowiła podglebie dla tego typu przymiotów jednostkowych, miała kontraktualny charakter: jednostki akceptują określone reguły dla realizacji własnych interesów. Etyka instytucjonalna wskazuje właśnie na tradycję Hobbesa, Hume'a, Spinozy, Rawlsa i Buchanana, która podsuwa nam wizję społeczeństwa (do pewnego stopnia także „wspólnoty”), w ramach którego współdziałanie jednostek dokonuje się dzięki możliwościom realizowania własnych, indywidualnych interesów ${ }^{31}$.

Poglądy te nie mają nic wspólnego $\mathrm{z}$ neoliberalną ideologią i fetyszyzowaniem wolnego rynku, aczkolwiek myślenie liberalne jest tu obecne. Etyka instytucjonalna (etyka ładu - Ordnungsethik) ma swoje korzenie w koncepcji Waltera Euckena, zgodnie z którą to państwo stwarza warunki dla wolnej konkurencji za sprawą ładu prawno-moralnego. Państwo też powinno dbać o to, aby wolny rynek nie przekształcił się w zmowę współczesnych potentes. Porządek, o którym myśli Eucken, nie zaistnieje dzięki odgórnym nakazom i zakazom, lecz dzięki takiej aksjologii ładu gospodarczego, która sprawi, iż ludzie dobrowolnie (we własnym interesie) podporządkują się normom prawnym i moralnym ${ }^{32}$. Nie wskazówki moralne, lecz ustrój gospodarczy decyduje o moralnym charakterze życia gospodarczego ${ }^{33}$.

${ }^{29}$ I. Pies [et al.], Moral commitments and the societal role of business. An ordonomic approach to corporate citizenship, „Business Ethics Quarterly” 2009, vol. 19, nr 3.

30 Zob. B. Friedman, op. cit., s. 40-41; A. Hirschman, op. cit., s. 50; J.B. Wight, Adam Smith and greed, "Journal of Private Enterprise" 2005, vol. 21, nr 1, s. 50.

${ }^{31}$ C. Lütge, op. cit., s. 12.

32 G. Szulczewski, Rozważania o miejscu etyki i moralności w teorii i praktyce gospodarczej, Warszawa 2013, s. 120-123.

33 Ibidem, s. 131-132. Warto też dodać, iż instytucje państwa mogą być obwiniane o załamanie się tego ładu. Światowy kryzys finansowy rozpoczął się od załamania się amerykańskiego rynku kredytów hipotecznych, za który najczęściej wini się państwowych regulatorów oraz politykę rządu federalnego. Szerzej piszę o tym w: J. Sójka, Polityczny wymiar sekurytyzacji kredytów hipotecznych, [w:] R. Kamiński, J. Sójka, Ekonomiczne i etyczne aspekty kryzysu gospodarczego, Poznań 2013, s. 77-92. 
W okresie niedawnego kryzysu znowu wróciło pojęcie chciwości i chęć piętnowania bankierów ${ }^{34}$. Wprawdzie załamanie gospodarcze ostatnich lat porównywalne być może tylko z tak zwaną wielką depresją lat 1928-1932, nie jest to jedyny kryzys w ostatnich dziesięcioleciach. Zawsze przy tej okazji, na przykład podczas serii bankructw - na czele z tym najbardziej znanym, czyli Enronu - etycy i niektórzy przedsiębiorcy powtarzali znane hasło "nigdy więcej”. Jednak takie sytuacje powtarzały się i będą się powtarzać. A zatem nie ma sensu etyka przedmodernistycznego napomnienia, która zamierzałaby umoralnić całe środowiska gospodarcze.

Próby przekształcenia egoisty $\mathrm{w}$ altruistę, wyzyskiwacza w dobroczyńcę, nie tylko są nieskuteczne, lecz przede wszystkim oparte na fałszywych założeniach, zgodnie z którymi rynek i konkurencja to sfera negatywnych namiętności i gry o sumie zerowej. Oparte są także na nieaktualnym obrazie świata i człowieka: chciwość jako grzech przestała być elementem skutecznej pedagogiki moralnej, stała się natomiast modnym tematem wytworów kultury masowej oraz częścią procesu „demokratyzacji pożądania” 35 .

Pamiętać też należy, iż żadna instytucja nie jest w stanie kontrolować ludzi niczym feudalni panowie. Nie nagradzamy naszych sług, tak jak czytamy o tym w przypowieściach biblijnych. Nie żyjemy w małych wspólnotach, w których bezpośrednie, czynione "twarzą w twarz" egzekwowanie moralności było możliwe. Możemy co najwyżej w ramach procedur demokratycznego państwa projektować normy prawne i toczyć dyskusje nad normami moralnymi. I nie da się $\mathrm{w}$ tej dyskusji pominąć realiów gospodarczych. Przy czym nie prowadzi do niczego dobrego charakteryzowanie mechanizmów gospodarczych jako opartych na chciwości, nieliczącej się z innymi chęci zysku i innych przywarach będących zaprzeczeniem dążenia do dobra wspólnego. Jak uważają współcześnie kontynuatorzy idei Euckena, nie da się wymusić realizacji norm moralnych wbrew podstawowym regułom gospodarczym. Karl Homann w tym duchu cytuje Józefa Kardynała Ratzingera, który miał powiedzieć, iż „moralność, [...] która sądzi, że może zignorować funkcjonowanie praw ekonomii, nie jest moralnością, lecz moralizowaniem, które jest zaprzeczeniem moralności"36.

\footnotetext{
${ }^{34}$ Chciałoby się zadać pytanie, dlaczego tak chętnie piętnujemy bankierów, a tak rzadko kierowców. Ruch drogowy w Polsce jest przecież źródłem permanentnego kryzysu.

35 J. Sójka, Chciwość czy kultura chciwości? Dyskusje nad źródłami kryzysu finansowego, [w:] Wzory kultury gospodarczej, "Człowiek i Społeczeństwo" t. XXXVIII, red. W. Banach, Poznań 2014, s. 165-185. „Demokratyzacja pożądania” obejmuje tutaj całe spektrum namiętności, czyli rozumiana jest szerzej aniżeli u projektodawcy tego wyrażenia; zob. B. McNair, Seks, demokratyzacja pożądania i media, czyli kultura obnażania, tłum. E. Klekot, Warszawa 2004, s. 30.

36 K. Homann, Profit and morality in global responsibility, [w:] Corporate Citizenship, Contractarianism and Ethical Theory. On Philosophical Foundations of Business Ethics, ed. by J. Conill [et al.], Surrey 2008, s. 86.
} 


\section{Common Good and Self-Interest as a Problem of Business Ethics}

\section{Summary}

The goal of this article is to argue in favor of such a type of ethical reflection which comes to terms with the unavoidable existence of competition and self-interest as a basic human motivation, which does justice to the market rules of the game, but, at the same time, does not allow itself to embrace the extremities of neoliberal ideology which a priori rejects any state intervention in the markets. Competition in a modern economy which resembles a positive-sum game, can be recognized as constructive element of the market leading to prosperity and economic development. Morality then cannot be construed as rules which favor only restraint, altruism and compassion but rather as a social regulator which creates conditions of fair competition, fair rules of the game. This kind of economic ethics has been elaborated by the followers of the so-called ordoliberalism of Walter Eucken. The ethics of order (Ordnungsethik) or institutional ethics has been focused on the legal and moral order created and safeguarded by a state. The article develops the idea of non-contradictory status of self-interest and common good within the modern economy as a basis for business ethics. 